revista ANTHROPOLÓGICAS

Ano 23, 30(1): 99-135, 2019

\title{
'Acordamos, Somos Cidadãos': os evangélicos e a constituição ética de si na relação com o político
}

Cleonardo Mauricio Junior ${ }^{\mathrm{a}}$

Este trabalho tem como objetivo analisar a constituição ética de si, na relação com o político, dos jovens crentes da igreja do pastor Silas Malafaia, a Assembleia de Deus Vitória em Cristo, no Rio de Janeiro. Levando em consideração os embates ocorridos na esfera pública brasileira em torno das questões relativas aos direitos sexuais e reprodutivos e que colocaram em lados opostos líderes das igrejas pentecostais e movimentos sociais, afirmo que os fiéis ordinários dessas igrejas têm recebido a incumbência moral de se posicionarem politicamente em suas vidas cotidianas, na defesa de temas caros aos seus sistemas de valores. 'Crente também é cidadão', é o que diz Malafaia aos seus liderados e, por isso, 'tem de se posicionar'. Pretendo mostrar, então, como os jovens dessa igreja assumem essa missão, principalmente em suas universidades, definindo suas condutas éticas em meio às tensões políticas que têm caracterizado a sociedade brasileira atualmente.

Pentecostalismo, Ética, Política, Crente-cidadão.

Os evangélicos ficaram alienados da vida social, como se fossem anjos, pensando q [sic] são exclusivamente espirituais. Acordamos, somos cidadãos.

(Silas Malafaia em sua conta no microblog twitter)

"Sou cidadão ou sou cristão?". A pergunta surge em uma das reuniões do Universe, grupo de jovens da Assembleia de Deus Vitória em Cristo (ADVEC) - a igreja do pastor Silas Malafaia, no Rio de Janeiro

a Doutor em Antropologia (UFPE). Pesquisador do Observatório de Religiosidades e Emoções (OCRE/LECC/PPGA/UFPE). Email: cleonardomj@gmail.com. 
- cujos participantes foram os principais interlocutores durante o trabalho de campo que realizei para minha tese de doutorado (Mauricio Junior 2019). Os integrantes do Universe reuniam-se periodicamente para discutir o que consideravam ser as adversidades enfrentadas pelos cristãos nas universidades. $\mathrm{O}$ objetivo dos encontros também era o de compartilhar e afinar os argumentos necessários para responder as interpelações que, todos ali sabiam, seriam feitas aos integrantes do grupo sobre temas como o casamento igualitário e a descriminalização do aborto, uma vez que seu líder maior, o pastor Malafaia, era (e ainda é) considerado um dos maiores adversários dos movimentos sociais pelos direitos sexuais e reprodutivos. $\mathrm{O}$ assunto daquele dia, uma demanda dos próprios participantes, tratava de entender as razões pelas quais os evangélicos passaram a se envolver tão intensamente na vida política brasileira. Eles estavam acostumados a verem seus representantes participando de campanhas para elegerem-se principalmente aos parlamentos das esferas municipal, estadual e federal.


Imagem 1 - Divulgação de reunião do Universe Fonte: Instagram oficial do Connect (juventude da ADVEC). 
Apesar de o grupo se reportar diretamente ao pastor responsável pelos jovens ${ }^{1}$, não havia necessariamente a presença de um membro da hierarquia oficial da igreja nas reuniões. Eram os próprios jovens, então, que organizavam as pautas e planejavam os encontros. Nesse dia, Davi, líder do grupo e quem geralmente conduzia as conversas, falava sobre a necessidade de a igreja (e aqui ele não se referia à sua igreja local, mas referia-se uma identidade evangélica nacional) ocupar todos os lugares de evidência, inclusive a política. Alex, antes de fazer a pergunta que dá início a este artigo, interpela Davi, questionando-o: "estar em todos os lugares, então, é uma atitude cristã ou política?". E continua: "eu vejo pessoas começando a pensar nisso e tendo um conflito. 'Sou cidadão ou sou cristão?"”

É justamente a respeito dessa relação entre o exercício de uma cidadania política e a constituição de sujeitos religiosos do que trata este artigo. Deparando-se com o dever de se posicionar politicamente, de barrar o avanço de grupos considerados ameaças ao equilíbrio moral da sociedade, ou ainda, diante do dever de serem protagonistas 'em todos os lugares', os evangélicos passaram a encarar novas demandas éticas informando sua constituição enquanto sujeito moral ideal. Dou o nome a esse fenômeno de constituição do crente-cidadão, no intuito de mostrar como a relação entre cidadania política e virtuosismo religioso estão imbricados no mesmo processo.

Essas novas demandas éticas, as quais, como disse, giram em torno da exigência de uma postura mais aguerrida na defesa dos chamados valores cristãos, estão resumidas em um sistema moral baseado na tomada de posição política compartilhado entre os membros da Assembleia de Deus Vitória em Cristo. Chamo esse código moral de pentecostaharsh, porque, ao contrário de como o pentecostalismo em Gana, como mostra Birgit Meyer (2004), vai a público a partir de seu entrelaçamento com a cultura, mais especificamente através do cinema, e deste modo, espalha-se suavemente pela esfera pública ganense, o pentecostalismo brasileiro, eu afirmo, apresenta um estilo baseado no peso do confronto. Enquanto o estilo do pentecostalismo ganense 
foi definido por Meyer (2004) como pentecostalite, a fim de enfatizar como ele se conduz sutilmente pela esfera pública (lite $=$ leve em inglês), na sua convergência com a dimensão do entretenimento, o código de conduta dos evangélicos com os quais convivi está fundado no estabelecimento de controvérsias (Montero 2015).

Meu objetivo, enfim, é dar conta da constituição do crente-cidadão entre os jovens do Universe. Para isso, primeiro, irei apresentar o código moral pentecostaharsh. Dois eventos servirão de momentos paradigmáticos para entender como este código moral foi objetivado: uma mensagem sobre a relação entre o cristão e a política; e um painel organizado pelo departamento de juventude da igreja, e pelos membros do Universe, que contou com a participação dos parlamentares ligados à igreja. Como disse, tomar posição a respeito de temas caros à igreja evangélica na vida cotidiana dos fiéis passou a fazer parte da constituição do sujeito pentecostal, e é o código moral pentecostaharsh que informa o regime de sensibilidades e a maneira ideal de se conduzir do crente-cidadão. Depois, falarei mais especificamente de como o crente-cidadão se constitui enquanto sujeito moral. Sendo o contrário de 'alienado social' (esta, uma categoria êmica), o crente-cidadão é o resultado de um projeto ético na busca por se tornar um certo tipo de pessoa, aquela pronta a mostrar suas habilidades no debate público quando for necessário defender os preceitos evangélicos.

O senso comum (o mais geral e o acadêmico) não trata como novidade entender a postura das igrejas evangélicas na esfera pública como uma conduta moral. No entanto, a moral como código prescritivo de um lado, e o comportamento do crente ordinário como receptor passivo das ordenanças deste código, do outro lado, é a tônica das análises. É preciso ir além de como as regras prescrevem comportamentos e voltar-se para entender a forma como os códigos morais são problematizados e como os sujeitos das ações morais deliberam a respeito deste código. Ainda mais importante, é preciso contemplar a forma como, através das práticas de si, os jovens crentes com os quais convivi buscam dar conta de conduzirem-se da maneira correta 
nos momentos de debate público, em outras palavras, como buscam tornarem-se crentes-cidadãos.

\section{O crente-cidadão e seus dilemas éticos: o desafio moral e as condições práticas de reflexividade}

Para dar conta dos momentos carregados de dilemas éticos no fluxo da vida dos crentes pentecostais com os quais convivi, tomarei como base o conceito de desafio moral (moral breakdown) de Jarrett Zigon (2007). Para desenvolver esse conceito, Zigon faz uma diferenciação entre, de um lado, a moral como o modo não refletido de se estar no mundo, onde o indivíduo se perde na familiaridade, e do outro lado, os momentos de ruptura moral que desarticulam essa familiaridade e conforto. Tais momentos acontecem quando um dilema ético se impõe aos indivíduos e eles se encontram forçados a se distanciarem (subjetivamente) do problema "para buscar uma solução, resolver o problema e lidar com a questão” (Zigon 2007:137).

Esse momento ético, que Zigon afirma ainda ser semelhante ao momento de problematização foucaultiano, é definido como uma tática, performada nos momentos de ruptura, com um objetivo determinado: regressar ao conforto dos momentos de familiaridade moral irrefletida. Assim como Simon Coleman (2018), não compartilho dessa definição de ética como um processo cujo fim seria o retorno ao modo não-reflexivo das disposições morais cotidianas, porque, no caso dos nossos sujeitos de pesquisa, os crentes pentecostais, o momento ético está diretamente ligado a uma escolha deliberada por situações desconfortáveis: os sujeitos pentecostais constituem-se moralmente na busca, e não na fuga, do risco. Irei complementar a análise de Coleman mostrando outro aspecto da constituição do crente-cidadão como sujeito ético: a forma como deliberam a respeito da modalidade ética que devem lançar mão, antes de assumirem os riscos na construção da pessoa que pretendem ser e na consolidação de como os outros os veem. Enfim, a noção de desafio moral (Zigon 2007) é importante para a construção de minha narrativa do crente-cidadão, uma vez que 
- e principalmente porque - meus sujeitos de pesquisa consideravam estar vivendo uma ruptura moral. Uma nova demanda ética lhes foi imposta, pois a vida de um bom cristão recebeu o acréscimo de uma dimensão cidadã, cujo principal elemento é a necessidade de se posicionar a respeito de temas políticos considerados importantes para os evangélicos na esfera pública.

Sendo assim, seguindo Keane (2014), a conduta ética dos sujeitos é definida em três instâncias. A primeira é a da autoconstrução e da avaliação, equivalente a um dos níveis de análise dos fenômenos morais apresentados por Foucault: aquele preocupado com as formas do sujeito se conduzir moralmente. A terceira instância trata do domínio da causalidade externa e pode ser comparado a mais um nível do fenômeno moral foucaultiano, desta feita, aquele do código moral. Para Keane, o objetivo é desfazer a distinção ontológica aguda entre o mundo da causalidade (natural ou sociológica) e aquele da avaliação, do autoconhecimento ético. Para isso, diz ele, é preciso prestar atenção à instância ética de segunda-pessoa, aquela da fala e da interação (Keane 2014).

Em resumo,

"O desafio que está diante da abordagem etnográfica é fornecer um relato da articulação entre os mundos vistos pela primeira e terceira perspectivas que não terminem simplesmente subordinando um ao outro, ou os colocando em realidades radicalmente segregadas. $\mathrm{O}$ que a abordagem alternativa que defendo faz, em parte, é chamar nossa atenção para a segunda pessoa, para a cena do discurso e da interação. Essa cena faz a mediação entre o self e o domínio da perspectiva da terceira pessoa, o domínio do qual o sujeito pode se ver de uma distância reflexiva" (Keane 2014:446).

Portanto, para que a ética seja entendida como reflexividade, sem cair na armadilha do subjetivismo, de um lado, ou ser resumida a um determinismo do outro lado, é preciso prestar atenção nas "condições práticas da reflexividade” (Keane 2014:451). É indispensável compreender, e isto é primordial para o argumento que irei apresentar sobre a constituição do crente-cidadão, que "a reflexividade é produzida pela 
dinâmica da interação entre as pessoas" (Keane 2014:451). Eu entendo os momentos de dilemas éticos, ou de desafio moral nos dizeres de Zigon, como necessariamente fazendo parte de uma instância de segunda pessoa, seguindo Keane (2014), na qual os crentes-cidadãos fazem um relato de si mesmos em reação à interpelação inerente à interação. Com isso, eles têm a oportunidade de verem a si mesmos da perspectiva da instância da terceira pessoa. Em suma, eu quero dizer que o crente-cidadão é um sujeito que avalia e também se autoconstitui, ou se autoconstitui enquanto delibera moralmente no momento da interação na qual foi chamado a dar conta de si.

\section{O código moral pentecostaharsh: reagregando esferas, alternando gramáticas e a estética do confronto}

A moral pentecostaharsh, portanto, pode ser descrita como uma perspectiva de terceira instância (Keane 2014) na relação com a qual os jovens pentecostais que estou focando para desenvolver meu argumento avaliam a situação, avaliam a si mesmos, bem como são avaliados pelos de sua comunidade nos momentos de demanda ética que apresentarei em seguida. Enfim, o crente-cidadão como projeto ético na direção de tornar-se um determinado tipo de pessoa tem suas virtudes a serem perseguidas delineadas na moral pentecostaharsh. Para descrever os elementos deste código, recorrerei a dois eventos que entendo serem paradigmáticos na revelação das características esperadas do crente-cidadão, celebradas, principalmente, pela liderança da igreja. Com isso, tenho também o objetivo de mostrar como a moral pentecostaharsh é compartilhada, ritualizada na igreja, a fim de que se internalize o tipo ideal do crente-cidadão. $\mathrm{O}$ primeiro momento é um sermão do pastor Silas Malafaia, realizado em um culto de domingo à noite (o mais popular da programação semanal da igreja), intitulado ' $O$ cristão e a política'. O contexto era a aproximação das eleições para prefeito do Rio de Janeiro em 2016 (estávamos no início do mês de agosto e o primeiro turno ocorreria dali a menos de dois meses), ocasião em que Marcelo Crivella do PRB, 
bispo licenciado da Igreja Universal do Reino de Deus e apoiado por Malafaia, viria a ser eleito.

O segundo evento que fará parte da minha análise deu-se pouco menos de um mês antes da pregação de Malafaia. Trata-se de um painel com a presença dos detentores de mandato legislativo ligados à igreja. Todos se tornaram parlamentares pela cidade ou estado Rio de Janeiro, sendo eleitos, principalmente, por receberem o apoio de Malafaia: Alexandre Isquierdo, vereador; Samuel Malafaia, irmão de Silas Malafaia e deputado estadual; e Sóstenes Cavalcanti, deputado federal, todos filiados ao então DEM, hoje Democratas. Além do vereador e dos deputados de Malafaia, também esteve presente o então deputado federal, Jair Bolsonaro, na ocasião filiado ao PSC.

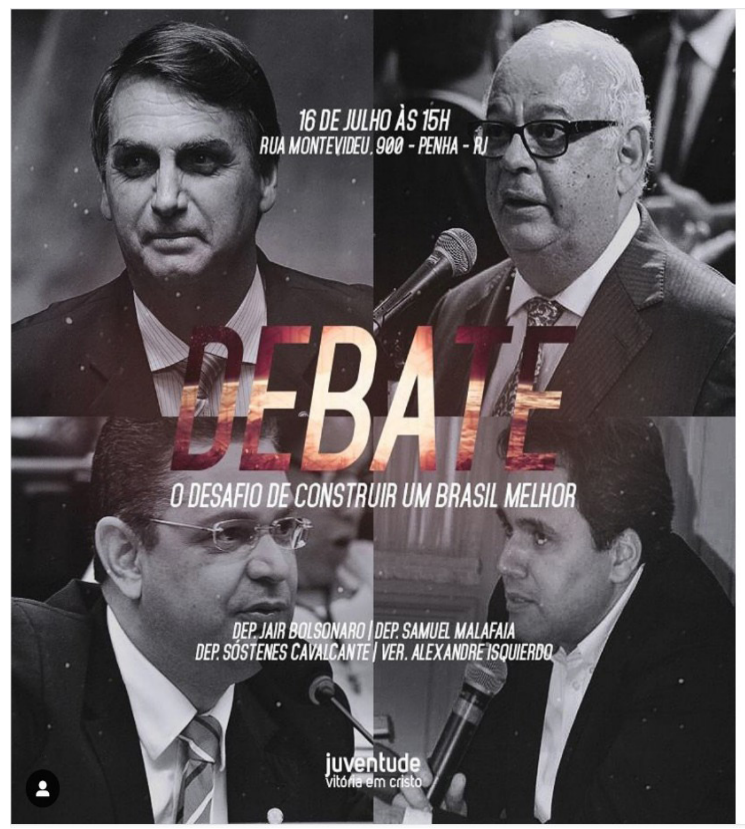

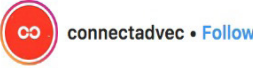

\begin{abstract}
connectadvec Nossa Conferência vai ser quente! Sábado à tarde teremos uma programação especial, com a presença de @jairmessiasbolsonaro @depsostenes @alexandreisquierdo e Deputado Samuel Malafaia em um debate sobre "O desafio de construir um Brasil melhor"! Não perde, sábado 15h no Templo Novo! \#lgnição2016

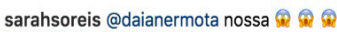

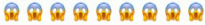

lidianyy_ @alexandre.bertin.10 se liga alexandre.bertin.10 @lidianyy_, se fosse em qualquer outro dia, eu iria com o maior prazer.. infelizmente, será no dia da estreia do Botafogo seu novo estádio.

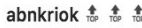

allanabarros1 Topppppppp

allanabarros1 Olha isso @rogerwilliam

$\bigcirc \bigcirc \uparrow$

220 likes

JULY 11, 2016

Log in to like or comment.

Imagem 2 - Divulgação do painel com participação dos parlamentares ligados à igreja. Fonte: Instagram oficial do Connect (juventude da ADVEC). 
Começo, então, com a prédica de Malafaia sobre o cristão e a política. Nela, o pastor baseia-se em dois textos bíblicos: o primeiro, quando Jesus dirige-se aos fariseus dizendo "Dai, pois, a César o que é de César, e a Deus o que é de Deus”. O segundo, quando Paulo, por sua vez, afirma "dai [a] cada um o que deveis: a quem tributo, tributo; a quem imposto, imposto; a quem temor, temor; a quem honra, honra”. Ao prosseguir com a hermenêutica dos textos, Malafaia aponta que Jesus e Paulo estariam mostrando que "a cidadania do céu” não anularia a "cidadania terrena” e, por isso, é preciso "cumprir sua função como cidadão dessa terra e cumprir sua função como cidadão dos céus”. No entanto, não basta entregar ao público evangélico uma intepretação do texto lido. Para uma disposição tornar-se modelo de conduta e regime de sensibilidades na tradição pentecostal, Malafaia sabe disso, é preciso que ela seja ritualizada e dramatizada junto e de acordo com os mitos bíblicos (Mauricio Junior 2016; ver também Campos \& Mauricio Junior 2013). Dessa forma, seguindo Durkheim, constrói-se não somente uma regra de conduta, mas se estabelece o desejo de segui-la (Durkheim 2008). E assim, ele cita mais uma passagem bíblica na ocasião em que Paulo, tendo sido preso injustamente, e torturado, reivindica sua cidadania romana, status desconhecido de seus agressores. Ao ser pressionado pelos magistrados para deixar a cidade onde havia sido preso e torturado, Paulo, segundo Malafaia, dá uma lição de cidadania. $O$ pastor faz a performance do mito bíblico:

Os magistrados pedem para ele cair fora e ele diz assim: "ei... que papo é esse? Eu nem fui julgado. Vocês me sentenciaram sem julgamento, mas eu não sou escravo, eu sou cidadão romano". [Aí] os caras tremeram. E Paulo não atendeu eles, não... foi fazer o que tinha de fazer. Então, tanto Jesus como Paulo, eles não estão anulando a cidadania terrena. O que nós precisamos entender é que [há] uma prioridade. Quando Jesus fala "buscai primeiro o reino de Deus e a sua justiça, e as demais coisas vos serão acrescentadas", o que Jesus está falando é de uma prioridade... A ordem de importância é o reino [primeiro], mas não significa que as coisas da vida são para serem desprezadas. 
O crente-cidadão, portanto, constitui-se enquanto sujeito com o religioso como prioridade, mas desenvolve, concomitantemente, suas habilidades como cidadão. E essas habilidades estão direcionadas para um debate qualificado na esfera pública. $\mathrm{O}$ que se requer, em outras palavras, é uma participação nos debates públicos caracterizada pela propriedade na argumentação. Na verdade, propriedade para vencer uma discussão com argumentação. A interação bem-sucedida nos momentos de debate público encontra seus parâmetros, então, no que fez Paulo: primeiro, conhecer os seus direitos, e depois, de posse deles, fazer os adversários tremerem.

No entanto, a conduta do crente-cidadão não deve se restringir a uma postura reativa. Deve-se, acima de tudo, buscar protagonismo. Citando mais dois textos bíblicos nos quais, mais uma vez, Jesus e Paulo exortam a, respectivamente, "resplandecer diante dos homens" e serem "astros no mundo no meio de uma geração corrompida e perversa”, Malafaia reforça:

Se eu tenho de resplandecer diante dos homens, perto deles e no meio deles, é [para estar] nas ciências, nas artes, na educação, no empresariado, no comércio, na diplomacia, na educação, na política, em tudo. Como é que vamos, resplandecer a luz de cristo, se estamos alienados da vida social? É diante e no meio! Tem que ter gente no judiciário, tem que ter gente no legislativo, tem que ter gente no executivo, tem que ter gente em tudo o que é área, na cultura, nas ciências, nas artes, tem que ter gente! Para que a luz possa brilhar no meio de uma geração corrompida e perversa.

Insistir em entender esta performance da prédica que estamos analisando (Mauricio Junior 2016), tentando separar o político e o religioso em departamentos, ao invés de entender o religioso, o político, e o ético produzindo-se mutuamente, leva a uma inevitável homogeneização de um fenômeno tão complexo e cheio de nuances. Nesta produção agregada do religioso, do político e do ético, o adversário escolhido por Malafaia é justamente aquele que opera de maneira inversa: mantendo o religioso desagregado do político, exilado, assim, na esfera privada. Esses, diz Malafaia, fazem uso da ideia de laicidade 
como subterfúgio para calar a voz dos evangélicos, deslegitimando a presença de cidadãos religiosos na esfera pública. $\mathrm{O}$ pastor, ao contrário, reagrega a religião na política, ou a política na religião:

O Estado é laico, isso é, não tem religião, mas ele não é laicista. Ele não é contra a religião. O Estado, isto é, o governo, não tem religião, mas o povo tem; e a política é a manifestação das crenças e valores do povo. Um dos maiores filósofos do nosso tempo, respeitadíssimo, Michael Sandel, filósofo da Universidade de Harvard, muito conceituado, ele diz assim: "é muito bem-vindo (sic) ao debate político as questões religiosas, porque fazem parte das convicções do ser humano"; e aí vem outra afirmativa: em uma sociedade livre, as pessoas podem pautar as suas convicções políticas em quaisquer ideologias, sejam elas religiosas ou não. Por algum acaso, Karl Marx vale mais do que Jesus? Quer dizer que os esquerdopatas e comunistas podem basear as suas ideologias em Karl Marx, e eu não posso me basear em Cristo? A [ideologia] de Karl Marx está falida, a de Cristo está de vento em popa!

Já se vislumbra aqui mais uma das características do crente cidadão, que eu vou nomear de estética do confronto. Os 'esquerdopatas' e os 'comunistas' seriam os adversários dos cristãos e o deboche, a pilhéria, enfim, o desafio, é um dos instrumentos utilizados ao se referir a eles, e ao se debater com eles - na verdade, contra eles. Por agora, quero mostrar que, mesmo operando no marco da reagregação entre religião, política e ética, o crente-cidadão precisa saber que a sociedade mais ampla entende esses âmbitos como esferas que exigem diferentes gramáticas a informar o discurso. Isso fica claro quando, momentaneamente, Malafaia reconhece que, na perspectiva dos outros, seus adversários, o cristianismo é somente mais uma ideologia. Sendo assim, Sandel e Marx já foram citados na mensagem e o intuito é que o crente-cidadão também o faça nos momentos de interpelação pública. Ainda há outros ativos a serem utilizados no intuito de enfrentar os momentos de debate público. Para refutar de vez os adversários que insistem em retirá-lo do debate público, Malafaia insiste:

Se as pessoas me disserem "pastor, vai pregar na igreja. Aqui não", eu cito o artigo $5^{\circ}$ da Constituição Federativa do Brasil, [que] na 
abertura, diz "todos são iguais perante a lei”. Eu posso ser religioso, o outro pode ser médico, o outro pode ser engenheiro, o outro ativista político. Eu tenho o direito de expressar as minhas convicções e ninguém vai calar minha boca. Que conversa é essa que eu não posso falar, quer dizer que eu deixei de ser cidadão porque eu sou pastor? Se eu não posso falar, o médico também não pode, o metalúrgico também não pode falar, o operário também... eles dizem: "fica dentro da igreja calado, pastor, para a gente poder fazer a cabeça do povo cristão com a nossa ideologia”.

Depois de citar um filósofo, fazer críticas à Marx e ao conceito de Estado Laico, mas sem deixar de estar em sintonia com Paulo, como vimos, Malafaia se conecta agora ao discurso jurídico da modernidade, e se baseia na Constituição para justificar sua participação no debate público. O que se está fazendo aqui é reunir os instrumentos necessários para vencer os debates na vida cotidiana dos crentes-cidadãos, quando as ocasiões surgirem. A estratégia é se preparar para um embate argumentativo.

O código moral pentecostaharsh tem, portanto, uma estética combativa. Como disse, vou chamá-la de estética do confronto.

E nesse confronto, por discordar de "quem defende aborto, quem defende liberação de drogas, quem defende casamento gay, quem defende ideologia de gênero", Malafaia afirma receber da "mídia” e do "politicamente correto", "as pechas de fundamentalistas, retrógrados e antiquados". "Uma banana para essa cambada", arremata o pastor. Para ele, é necessário revidar à altura e mostrar que os crentes não seriam retrógrados, antiquados e despreparados. Pelo contrário, na sequência de sua mensagem o pastor atribui à Reforma Protestante conquistas consideradas como oriundas dos setores de esquerda:

Antes de mostrar que os Direitos Humanos e a escola pública seriam, na verdade, resultado da Reforma, ele desafia: "eu vou acabar com esses caras". E continua:

Essa daqui eu gosto, chama aí os petralhas, chama aí a cambada de comuna... A escola pública veio da reforma protestante. Quem tirou da igreja o domínio da educação foi a reforma protestante, não 
foi nenhum conceito de Engels ou de Marx que inventou a escola pública. Palhaços!

E, continuando a falar da educação, Malafaia afirma que ela estaria contaminada por uma ideologia de esquerda e, por conseguinte, a igreja não pode cruzar os braços diante dessa constatação:

Esses caras ideologizaram toda educação... doutrinaram na sua base de esquerda; e nós estamos iguais a uns trouxas olhando para isso.

Se o crente-cidadão, como vimos, não é alienado social e, agora, entende que não é 'trouxa', permanecer inerte, então, não é uma opção. E Malafaia coloca a culpa dessa inércia primeiro na própria igreja. Isso colabora com meu argumento a respeito de os crentes de sua igreja estarem vivendo um desafio moral no nível do grupo (Zigon 2007), uma vez que, diferente de outrora, quando se preocupavam apenas com seu crescimento espiritual, tornou-se necessário posicionar-se politicamente. Política, ética e religião foram reagregadas no sujeito, ao mesmo tempo "biológico, psicológico, sociológico e espiritual":

Lamentavelmente muitos líderes cristãos incutiram na cabeça do povo que eles eram apenas seres espirituais, e alienaram o povo da sociedade... Jesus trata o homem como um ser biológico, psicológico, sociológico e espiritual.

Se ainda havia dúvidas até ali entre os presentes a respeito da necessidade de se posicionar politicamente em suas esferas cotidianas, era necessário dissipá-las. E Malafaia encerra a mensagem com uma convocação:

Não vou ficar calado! Você não tem que ter medo não, de onde você trabalha, onde você estuda... você não tem que ter medo do ciclo social; você foi feito para brilhar no meio de uma geração corrompida e perversa. Atos capitulo 17, versículo 6 diz: "esses que tem alvoroçado o mundo chegaram até nós”. Nós estamos aqui para alvoroçar, isso é, para confrontar, para mostrar quem tem um estilo de vida superior. Você tem que entender isso, meu irmão.

E é no encerramento do painel com os membros do legislativo municipal, estadual e federal ligados à igreja, com a participação do 
deputado Jair Bolsonaro, que a forma desse confronto fica ainda mais clara. Após as perguntas direcionadas aos convidados, o pastor Malafaia traz, nas considerações finais, o exemplo de uma garota que teria enfrentado sua professora ao sair em defesa do próprio Malafaia. Durante uma aula em que a professora teria acusado o pastor de reiteradas condutas homofóbicas, a garota retruca e Malafaia assim descreve a situação aos presentes:

Meu irmão, a guria botou quente em cima da professora e a professora fugiu... A professora cita Bolsonaro, Malafaia, Feliciano e esculhamba com a gente. Aí a garota diz assim: "E por que [eles são homofóbicos]? Porque eles falam contra uma prática? E quem disse que isso é homofobia?"... Rapaz, a guria enfrenta a professora... "Professora, me responda. Isso é opinião [não é homofobia]". Encarou, e ela [a professora] fugiu da garota. [E quem fez isso foi] uma menina!

Uma menina! Enquanto Malafaia exclamava que uma menina tinha se levantado como crente-cidadã na escola, instava a todos a fazerem o mesmo. É preciso lembrar que se desenrolava ali um evento da juventude. Na amostra dos jovens da igreja com os quais convivi, a maioria era universitária. Ouvir a construção do crente-cidadão ideal como alguém que se levanta no meio da sala para defender os valores cristãos, poderia soar como um desafio inalcançável. Mas se aquela garota podia fazê-lo, 'uma menina', Malafaia repetia, todos ali eram capazes. Contribui, também, para a internalização da estética do confronto a percepção de que, principalmente na universidade, os crentes encontrariam um campo de batalha incessante. Sobre isso, Malafaia diz ainda:

Ou vocês vão se posicionar, ou os caras vão te pressionar o tempo todo... eu tô muito preocupado e não é com o Evangelho. Quem defende o evangelho é Cristo. Tô preocupado com defesa do evangelho não. Tô preocupado é com você, pra você não sucumbir diante da pressão da maioria. Maioria lá [na universidade], porque tá sendo doutrinado. Você não pode se calar. Mostra tua cara!... ... Perseguição? Vai lá na escola e diz que você é membro da igreja de Malafaia, vai lá. Abre a boca lá e fala. É isto o que vocês têm que mos- 
trar: "Olha aqui, gente. Que democracia é essa que vocês querem, que só porque eu sou contra a ideia de vocês eu sou massacrado?"

Assim, com a apresentação da mensagem e da convocação de Malafaia no painel com os políticos, espero ter deixado claro os elementos que compõem a moral pentecostaharsh. Eles mostram como o crente-cidadão deve ser, seu comportamento, habilidades e virtudes. Antes de tudo, é preciso assumir a postura oposta à de um alienado social. Mais do que isso: é preciso buscar o protagonismo. Como disse Malafaia, mostrar que eles possuem "um estilo de vida superior". Os adversários, nas interpelações cotidianas a respeito de temas caros aos valores evangélicos, tentarão desagregar religião, ética e política. $\mathrm{O}$ crente-cidadão precisa, no entanto, reconectar essas esferas. Ao mesmo tempo, no entanto, deve aprender a transitar entre as gramáticas que informam os discursos esperados em cada uma delas. É preciso, então, preparar-se para o confronto e 'mostrar a cara'.

\section{A constituição do crente-cidadão}

Até aqui, apresentei as virtudes necessárias para que um membro da igreja de Malafaia seja considerado um crente-cidadão. No código da moral pentecostaharsh existe o imperativo de se posicionar e não se calar nos momentos de debates/embates públicos, e é preciso fazê-lo com a habilidade de alternar entre códigos gramaticais relativos ao político e ao religioso. Isso demanda um conhecimento secular na busca da reversão de uma imagem de ignorância e despreparo dos evangélicos e, por fim, estabelece a busca por protagonismo. Não obstante, por mais taxativas que sejam as normas de um código moral, como diz Faubion (2001), há sempre uma lacuna entre "o mais categórico dos imperativos e as contingências inquietantes que incidem sobre nossas tentativas de fazer a coisa certa" (2001:85). A conduta virtuosa, diz ele ainda, pede a formulação de um catálogo de regras, "no entanto, por mais instrutivo que seja, tal catálogo moral nunca poderia servir como um guia de ética exaustivo" (2001:85). 
Era preciso, então, tentar compreender como esse código era acessado, colocado na prática, negociado, ou, talvez contornado pelos meus sujeitos de pesquisa. Sendo assim, questionei meus interlocutores acerca de temas que suscitassem dilemas éticos no intuito de provocar uma problematização, nos moldes descritos por Foucault: tomar distância em relação ao assunto em questão, gerando uma reflexão sobre a instância de terceira pessoa (Keane 2014). Umas das perguntas recorrentes era qual seria a atitude deles se estivessem no lugar de Kim Davies, tabeliã americana que se negou a realizar o casamento de um casal gay, alegando incompatibilidade com suas crenças $^{2}$. Ela invocou a 'autoridade de Deus' para se negar a emitir licenças de casamento para casais homossexuais. Presa devido às suas convicções, já que, meses antes, a Suprema Corte americana havia legalizado o casamento entre pessoas do mesmo sexo em todo o país ${ }^{3}$, a história de Davies tornou-se um caso bom para pensar junto com meus interlocutores a respeito de suas condutas nos momentos de 'desafio moral' (Zigon 2007).

Sendo assim, Andreia, 23 anos, convertida há quatro, estudante de Comunicação na UFRJ (campus fundão), negra e moradora da Penha, ratifica a postura da tabeliã americana e emenda: "Eu também não faria [o casamento], eu seguiria minha lei cristã e provavelmente seria presa”. Alex, 24 anos, convertido há nove, branco, estudante de engenharia na UERJ, corrobora com a decisão de Andreia e explica sua resolução do dilema em mais detalhes:

Então, na situação dela, eu não faria o casamento, eu me negaria também porque existem coisas certas e coisas erradas... No caso dela houve um choque porque ela é cristã, não é? Aí têm os dois lados... nós temos as leis do nosso mundo e temos leis que são sobrenaturais, [...] do nosso mundo espiritual, as leis da palavra de Deus. Entre fazer o certo aqui ou fazer o certo pelo mundo espiritual, ela resolveu fazer o certo pela religião dela e é o mesmo que eu faria.

Alex é contra o casamento entre pessoas do mesmo sexo porque, para ele, trata-se de uma estratégia do 'movimento gay' para que eles 
consigam, futuramente, casar na igreja mesmo à revelia dos pastores. Andreia, por outro lado, não comunga da ideia de um plano arquitetado pelo 'movimento gay' para obrigar igrejas a realizar casamentos e afirma não ser contra o casamento entre pessoas do mesmo sexo. Especialmente, não é contra a equiparação entre a união estável homoafetiva e a realizada entre homem e mulher. Ela também não se opõe à resolução da Comissão Nacional de Justiça que, em 2013, obrigou os cartórios de todo o país a realizarem casamentos civis entre casais do mesmo sexo ou a converterem a união estável homoafetiva em casamento civil. Ainda assim, Andreia afirma que sua participação na realização de uma união homoafetiva iria de encontro às suas crenças. Eu pergunto:

- Mesmo não vendo problemas no casamento civil entre pessoas do mesmo sexo você não realizaria o casamento como tabeliã? - Não, porque, civilmente falando, eu não vejo problema. Eles têm o direito. Mas minha crença espiritual está acima do meu status como civil e eu não devo participar dessa celebração.

Arthur, 26 anos, dezoito de convertido (converte-se ainda criança, aos oito), branco, cursando mestrado em engenharia química na UFRJ, tem a mesma opinião de Alex a respeito do casamento entre pessoas do mesmo sexo: a união estável seria apenas um degrau em um objetivo maior que seria casar dentro das igrejas. No entanto, ele afirma que teria de realizar o casamento:

Apesar de ter as minhas convicções, né? Eu tinha que respeitar o Estado em que eu convivo, as leis do meu Estado. Então, eu tinha que acabar fazendo. Eu tinha que fazer o casamento deles, eu tinha que respeitar.

Andreza, 21 anos, convertida há três, branca, estudante de nutrição na UERJ, moradora da Vila da Penha, acompanha Andreia ao não ver problemas na união homoafetiva ("é um direito deles, como qualquer pessoa”). Mas não acompanharia esta última em sua decisão de não realizar o casamento. Como cristã, Andreza afirma que a tabeliã não estaria errada em manter suas convicções contra o casamento 
homoafetivo, no entanto, diz que "enquanto profissional, ela estava errada". E continua:

Se ela acha que o que ela está fazendo, sei lá, está dando margem para o pecado, ou de alguma forma está ajudando, sendo conivente com aquilo, ela troque de emprego... se aquilo me incomodasse ao ponto de estar infringindo as minhas ideologias cristãs, eu deixaria o emprego, entendeu? Mas enquanto profissional, a meu ver, ela está errada. Ela tem que ceder, se aquilo é lei, ela concordando ou não.

Fica mais claro, então, o que falei, citando Faubion (2001), a respeito de um código moral não poder abarcar por completo as situações contingentes dos sujeitos éticos em construção. Ao serem interpelados sobre o que fariam em casos de dilemas éticos, os jovens crentes com os quais convivi problematizam as situações em termos que ainda não haviam pensado antes, e, além disso, o fazem diante do pesquisador (e a isto eu imputo o fato de se referirem às suas convicções religiosas como ideologia). Andreia, por exemplo, afirma que se recusaria a fazer o casamento homoafetivo porque isso iria de encontro à sua fé (apesar de não ser contra o casamento em si. Apenas não poderia, segundo ela, tomar parte em sua concretização), enquanto não vê problemas na descriminalização do aborto (deduz-se que, pelos mesmos motivos, ela não seria a médica a realizá-lo). Por outro lado, Andreza, que disse ser necessário submeter-se à ética da profissão e realizar o casamento, não cede no que diz respeito à descriminalização do aborto e afirma rejeitá-lo em qualquer ocasião. Sobretudo, o não alinhamento do discurso dos entrevistados mostra uma heterogeneidade na constituição de si enquanto sujeito ético, gerando diferentes interpretações, avaliações e condutas morais.

O que pretendo deixar claro é que há espaço para os processos de deliberação moral nos momentos de demanda ética, mesmo considerando o poder prescritivo do código da moral pentecostaharsh, e essa deliberação abre espaço para diferentes condutas éticas na mesma comunidade moral. É necessário, portanto, prestar atenção nas 
condições práticas de reflexividade (Keane 2014) a fim de entender como os jovens crentes constituem-se eticamente a si mesmos. É na interação, ou seja, na intermediação que a instância ética de segunda pessoa faz entre as demais, de primeira e terceira pessoa, que se decide a melhor maneira de conduzir-se eticamente. Enfim, a definição da situação está diretamente ligada à definição da conduta. Para isso, era necessário voltar o foco metodológico para as interações entre os jovens crentes e seus adversários nos embates públicos a fim de melhor compreender como eles se conduziam eticamente em relação ao código moral pentecostaharsh. Direcionei minhas perguntas, então, para esses momentos de debate em suas faculdades.

No que diz respeito à vida universitária, meus interlocutores consideravam estarem imersos em um ambiente hostil. Malafaia citou, nas considerações finais do painel com os políticos ligados à igreja, como o ambiente da universidade era intolerante com os evangélicos, especialmente com os de sua igreja. Querendo se contrapor à narrativa dos setores de esquerda, afirmou que a verdadeira perseguição poderia ser vista nas universidades, contra os jovens ali presentes: "Vai lá na escola e diz que você é membro da igreja de Malafaia, vai lá. Abre a boca lá e fala". Mas como é, na prática, essa convivência com a hostilidade, e como o projeto ético de se tornar um crente virtuoso se desenrola nesse contexto onde a expectativa é lançar mão da estética do confronto?

\section{. Contra a hostilidade: confronto ou posicionamento contextualizado?}

Débora tem 23 anos, é casada, formada em Serviço Social pela UFRJ, branca e membro da ADVEC desde os 13 anos. Ela é diaconisa da igreja, além de ser uma das líderes de um evento realizado mensalmente para as jovens conversarem sobre o papel da mulher na vida cristã. A narrativa de Débora sobre a discussão ocorrida em sua turma para saber se o convite da festa da formatura teria ou não um agradecimento a Deus, mostra como os jovens crentes com os quais 
convivi na ADVEC entendem estarem frequentando um ambiente hostil à sua fé na faculdade. Uma votação foi feita para decidir sobre 'a presença de Deus' no convite e, por fim, o voto de um evangélico ajudou a fazer com que o 'não' ganhasse. Débora me diz que foi tomar satisfações do seu irmão de fé imediatamente. Ao saber o motivo pelo qual o referido irmão teria votado para que não houvesse referência a Deus no convite ("havia pensado nos outros e um ateu não iria gostar"), Débora replica: "Aqui eles te violentam todos os dias. Todos os dias a faculdade te violenta com relação às tuas crenças". E para mim, ela complementa:

A gente fala tanto de democracia... um curso que fala tanto de democracia e liberdade de expressão, mas só existe liberdade de expressão até onde eles querem, porque o cristão não tem liberdade de expressão, ou pelo menos na cabeça deles não deveria ter.

Hanna corrobora com o sentido de se conviver em um ambiente hostil e não se diz à vontade para emitir suas opiniões na faculdade:

É um ambiente totalmente hostil e eu sinto que eles não querem saber [de] minha opinião em nada... Eu sinto que eles têm um espaço para falar e a gente não tem nenhum; lógico que a gente pode ganhar esse espaço se posicionando, mas é muito difícil.

A tentativa de conquistar esse espaço ocorre com Beatriz. Apesar de afirmar não ser interpelada a todo tempo na PUC com provocações no que tange a sua fé, Beatriz dá um exemplo de um momento em que se sentiu forçada a se posicionar para defender seu pastor. Frequentando as aulas de uma professora que citava costumeiramente o pastor Silas Malafaia como exemplo de conduta homofóbica, Beatriz afirma que, um dia, decide responder. Nesta ocasião a professora teria dito que, apesar de ter interpretações retiradas equivocadamente da Bíblia sobre a questão da homossexualidade, "Malafaia achava que só a opinião dele era a certa”. Beatriz espera o final da aula para confrontar a professora:

"Professora, olha só, você falou isso ao longo da aula, falou a respeito do pastor Silas Malafaia. Eu sou membro da igreja do pastor 
Silas Malafaia. Eu conheço o que ele fala, eu sei o que ele fala. Inclusive toma aqui um convite 4 para a senhora ir lá ouvir o que ele está falando também ao vivo, na íntegra, antes de a senhora falar mais alguma coisa a respeito dele. Mas, a senhora falou a respeito de interpretações da Bíblia e tudo mais, especialmente nessa questão relativa a homossexuais... olha só, isso não é uma questão de interpretação, é questão do que está escrito de fato na Bíblia. E está escrito, ....". Eu peguei trechos, peguei de Coríntios: "Olha só, tem como a pessoa interpretar de forma diferente do que está aqui? Isso daqui é o que está escrito, não tem como essas palavras terem um sentido diferente deste; é um sentido bem claro. Qualquer coisa [a mais] eu te explico porque a ideia que a senhora tem é uma ideia errada".

E finaliza me dizendo: "Eu tento ser o mais calma possível na hora de conversar sobre essas coisas".

Débora, Hannah, Andreza e Beatriz mostram como elas entendem estarem vivendo em um ambiente que não as aceita em sua totalidade, não respeita sua fé. Apesar disso, a estética do confronto não é acionada em todos os momentos nos quais os valores cristãos, de acordo com o código moral pentecostaharsh, deveriam ser defendidos. Ainda que levantar-se e tomar uma posição pública, como fez Beatriz, é o comportamento esperado, muitos dos meus interlocutores deliberam sobre a necessidade de fazê-lo. A respeito de defender o pastor Silas Malafaia em uma situação semelhante à de Beatriz, por exemplo, Andreza responde:

... Eu acho que o pastor Silas sabe muito bem se defender sozinho, ele tem advogados. Eu não vou ser advogada do pastor Silas, eu vou defender aquilo que eu acredito, entendeu? Aquilo que eu, Andreza, acredito. A forma como ele fala, a forma como as pessoas entendem, as formas como as pessoas veem, é um problema delas, não é meu, não é do pastor. Então assim... na maioria das vezes eu fico calada. Eu só falo "gente, vamos lá [na igreja] para vocês conhecerem”, porque eu ficar falando, debatendo, não vai adiantar.

A fala de Andreza parece se contrapor aos elementos do código moral pentecostaharsh delineados anteriormente. Além da declaração inesperada para este pesquisador de não ser "advogada do pastor Si- 
las", Andreza afirma que, na maioria das vezes, escolhe o silêncio. Ela estaria se contrapondo, então, às recomendações do seu pastor de não ficar calada "no meio de uma geração pervertida e corrupta"?

Não há aqui, necessariamente, um rompimento com o código moral pentecostaharsh, mas uma deliberação a respeito dessa instância de terceira pessoa, promovida pela forma que se estrutura a interação. A estratégia é posicionar-se no contexto mais restrito das amizades construídas na faculdade. Hanna diz: "Eu acho muito difícil [confrontar abertamente]. Quando eu me posiciono, de chegar e falar alguma coisa é numa roda menor. Se acontece algum debate, é mais entre amigos, porque quando está a turma toda é complicado”. Eu insisto na questão:

- Mas você já passou por situações de alguém te constranger com coisas do tipo: "ah, essa daqui é da igreja de Malafaia; essa daqui é fundamentalista"...

- Não

- Não?

- Sabe por que?... Talvez ninguém tenha te falado isso, que não. Mas

é porque eu tenho uma postura muito de respeito com as pessoas, e eu acho que por mais que elas queiram falar alguma coisa para atacar o que eu acredito, assim diretamente, elas não vão fazer. Porque a gente construiu uma relação... Se eu estou com pessoas que eu conheço, como eu os respeito, e eles a mim, pode ser até que eles falem coisas quando eu não estou, mas nunca me atacaram diretamente, entende?

Por fim, Larissa ratifica o posicionamento político contextualizado e refletido:

Normalmente, eu não sou uma pessoa muito de levantar no meio da sala [e dizer] "eu sou contra isso"... Eu procuro fazer isso com as pessoas que convivem comigo e quando alguém me pergunta de fato, de maneira direta, aí eu falo... embora minha posição seja contrária a essas coisas, as pessoas não costumam me perguntar muito, porque eu fico mais na minha.

Onde está a estética do confronto? Onde estão também o deboche e a pilhéria vistos na prédica de Malafaia? Os 'esquerdopatas', os 
'comunistas', e a 'petralhada' que aparecem lá, aqui se tornam os colegas de faculdade e uma "postura muito de respeito com as pessoas", como disse Hanna, tem lugar. Andreza, Hannah e Larissa parecem não ter vindo 'para alvoroçar'. A melhor forma de se conduzir eticamente passa, portanto, além da reflexão a respeito da hora certa em que as coisas devem ser ditas, pela melhor forma de fazê-lo. Quando é o momento de entrar em um embate argumentativo e quando é o momento de calar, recuar e deixar de fazê-lo? Em suma, em que situações o posicionamento contextualizado dá lugar ao 'mostrar a cara'?

\section{. Os embates: 'Bíblia para converter' e 'argumentos plausíveis' para debater}

Débora 'mostrou a cara' na universidade. Em uma aula na faculdade, ela conta como interpelou sua professora que, segundo ela, "teria comparado um feto a um alface" ao dizer que abortar seria "como se a gente arrancasse um pé de alface"

Eu falei: "professora, a senhora tem nocão do que tá falando? Você comparou um ser humano com uma alface.

- ... Mas, a medicina mostra que não há sofrimento para o feto.

- Mas a medicina não comprova, comprova? Comprova o que? Se em um mês, se em quatro semanas a criança já tem um sistema nervoso feito. Quem é que me garante que ela não tem pensamento ali? Quem é que me garante que ela não sofre?"

E interrompe a narrativa para me dizer, com um olhar provocativo: "Se é pra ver pela ciência, vamos falar sobre ciência, então". E continua:

E ela ficou com raiva porque ela falou assim: "- você é de igreja, não é?

- Sou de igreja, mas eu tô argumentando com a senhora aqui sem ser (ela faz o sinal de aspas enfatizando) 'de igreja'. Tô falando como estudante, questionando a senhora, porque a senhora está fazendo uma comparação esdrúxula”.

Débora decide confrontar a professora porque é da igreja, no sentido, primeiro, de que a sensibilidade moral desenvolvida contra o 
aborto é burilada em meio à sua comunidade de fé e, segundo, porque a coragem reunida para interpelar a professora também vem de sua vivência na igreja. Quando pergunto se aprendeu a posicionar-se dessa maneira na ADVEC, ela responde: "eu sempre fui questionadora. Mas, da metade da faculdade pra cá, eu comecei a me posicionar mais... com certeza tem a influência da igreja, de você saber que o crente não é burro". No entanto, ao estabelecer um confronto na sala de aula, ela o faz 'sem ser de igreja', no sentido de alterar seu código gramatical em busca de argumentos científicos. Peço para que ela me conte mais sobre o que tinha mudado exatamente "da metade da faculdade pra cá", quando, segundo ela mesma, passou a se posicionar mais. Ela diz:

Então, eu não tinha tanta base. Só podia falar da Bíblia, mas essas pessoas não acreditam na Bíblia, então vou falar o que da Bíblia? Você tem que usar argumentos plausíveis para eles. Não é para falar da Bíblia para eles. Você vai falar [da Bíblia] quando é para a pessoa se converter e não na hora de vencer um debate, porque você não vai conseguir.

"Vou falar o que da Bíblia"? A questão de Débora pode parecer, à primeira vista, uma resignação com relação ao entendimento dos argumentos religiosos como pertencentes a um modo de razão defeituoso (Taylor 2011:51). Não se trata disso. A Bíblia não é menos importante como fonte de conhecimento nas diversas esferas da vida destes jovens crentes. $O$ entendimento, na verdade, é de que ela não deve ser usada nas discussões a respeito de temas caros à opinião pública, menos porque falta plausibilidade em seu conteúdo, e mais porque se trata de um idioma incompreensível aos que não compartilham de sua fé, de sua tradição. A tradução, nos termos de Habermas (2014), ou como venho chamando até aqui, a alternância de códigos gramaticais, dá-se, portanto, porque aos interlocutores não-evangélicos falta a capacidade de alcançar o argumento bíblico.

É interessante notar como as incapacidades se espelham. Habermas - eis a crítica de Taylor (2011) - atribui uma relação de incapa- 
cidade entre a religião e a razão pública, havendo a necessidade de os cidadãos seculares servirem de tutores para os cidadãos religiosos conseguirem transpor seus argumentos para uma discussão mediante razões. Aqui, são os jovens crentes que entendem estarem se deparando com a incapacidade dos cidadãos não-religiosos de compreenderem o sentido da argumentação baseada no conhecimento bíblico, tomado como superior, e como verdade. A solução é acessar um idioma compreensível a todos. No entanto, a Bíblia não cumpre o papel de uma razão defeituosa, nem é compreendida exclusivamente como fonte de fé. Conhecimento e Fé são reagregados, portanto, e os argumentos científicos não concorrem com os argumentos bíblicos. Mais do que um cumprimento à risca do proviso rawlsiano (a tradução da razão privada em pública), o que se tem é um borramento das razões privada e pública. Trata-se, enfim, da construção de uma confluência entre argumentos científicos e argumentos bíblicos. Assim diz Beatriz:

Então a gente tem que buscar e se preparar espiritualmente e tem que saber o que a gente crê; que em primeiro lugar a nossa regra de vida e aquilo que diz para gente o que é certo e errado, é a Bíblia; e se a Bíblia é a palavra de Deus, e a palavra de Deus é verdade, então aquilo que está fora dela, que é o mundo, a natureza, a ciência, vai comprovar aquilo que está escrito na Bíblia de alguma forma. Porque nada do que está na Bíblia vai estar ali à toa, ou vai ser provado como mentira. A intenção é buscar essas coisas, extrabíblicas, para comprovar nossa visão bíblica, mas sem falar que ela é Bíblia, para o nosso argumento ter algum tipo de validade no âmbito da faculdade.

Pode-se dizer também, no que diz respeito à constituição dos sujeitos, que há um borramento entre o cidadão religioso e o cidadão secular apresentados por Habermas (2014). Tem-se, do mesmo modo, uma re-agregação dos conhecimentos, ao invés de uma divisão das facetas religiosas e políticas do sujeito. É do crente-cidadão que estamos falando. Beatriz mostra, então, na prática, como constrói seu argumento:

Por exemplo, [se me perguntam] "ah Bia, você prefere que crianças fiquem em um orfanato, ao invés de serem adotadas por pessoas 
do mesmo sexo? ”. Eu falo: "quais são as consequências psicológicas para uma criança que é criada por dois pais ou duas mães? ”. Existem estudos que mostram que as consequências psicológicas são profundas? São... tornam ela um adulto com mais possibilidade de algum tipo de problema, ou coisa do tipo. Existe? Então, eu mostro isso. ... Então a gente pega esses estudos sociológicos, estudos históricos e etc. e mostra porque que isso não funciona na prática... Porque é pedir para ser atacada, vir numa faculdade e falar "ah não, porque a Bíblia diz que é errado”. Não tem a mínima lógica isso.

Ainda que o sujeito religioso e o sujeito político sejam re-agregados no crente-cidadão, é preciso reconhecer que o argumento bíblico é marginal, considerando a economia moral da esfera pública. Passa por esse reconhecimento a admissão de Beatriz de que "é pedir para ser atacada" trazer argumentos bíblicos para o debate na faculdade. Assim como disse Débora, quando afirmou não haver como vencer um debate recorrendo à Bíblia. Ou seja, os jovens crentes com os quais convivi entendem e aprendem a operar de acordo com a economia moral da esfera pública, engajando-se em suas instâncias, reconhecendo as regras vigentes. E se a moral pentecostal é harsh, a esfera pública também o é. Débora, por exemplo, teve o seu argumento desqualificado porque era 'de igreja'. Aqui é importante mencionar como entendo a esfera pública: como instâncias discursivas vindo à tona a partir de um processo comunicacional organizado em torno de temas e que possui sua economia moral. Vejamos a participação de Andreza em uma aula de Antropologia na qual o professor organiza um debate a respeito da descriminalização do aborto e divide aleatoriamente a turma entre os que argumentariam contra e a favor. No sorteio, ela cai no grupo dos 'contra o aborto' e logo toma conta da discussão.

[Apesar de que] em nenhum momento eu falei de religião, ele [o professor] entrou [na discussão]: "ah, você está falando isso porque você é religiosa". Eu falei: "não, eu não estou falando de religião”. Aí ele ficou se exaltando... foi ficando nervoso. Eu estava argumentando que o direito à vida não cabe somente à mãe, mas sim à criança que está em formação... Há inúmeros artigos científicos que mostram que desde a formação você tem o tubo 
neural formado, você tem o coração batendo, você tem uma massa de células que está em desenvolvimento. Aquilo é vida! São cientistas, que são ateus, que são agnósticos a maioria deles, e eles falam: aquilo ali é vida. É uma vida que está em desenvolvimento. A gente não tem como negar nisso, foram esses argumentos que eu fui utilizando, e ele foi ficando possesso... justamente porque eu não falei em nenhum momento sobre religião e ele queria de fato que eu falasse. Ele queria me cansar para que em algum momento eu recorresse à minha fé, mas em nenhum momento eu falei.

Assim, as interações discursivas que demandam com mais intensidade os elementos da moral pentecostaharsh são caracterizadas por essa deslegitimação do argumento religioso no desdobramento da discussão. São as condições práticas de reflexividade das instâncias de esfera pública política nas quais os jovens crentes se engajam que definem a situação como harsh. Então, é hora de lançar mão da estética do confronto e dos argumentos não-religiosos.

A moral pentecostaharsh mantém, então, sua característica de operar a partir da alternância de códigos gramaticais (religioso-político, religioso-científico), mas não nos deparamos com a estética de confronto no mesmo vigor ritualizado tanto no culto quanto no painel liderados por Malafaia.

É interessante notar que um jovem crente fazendo uso de argumentos não-religiosos para debater temas seculares parece perturbar as categorias de entendimento dos participantes não religiosos do debate. Está-se diante de um fenômeno contaminado, impuro (matter out of place), nos dizeres de Mary Douglas. É preciso, então, purificar a discussão e restaurá-la ao estado anterior das coisas, desagregando religião e política: "Você está falando isso porque é religiosa", foi o que o antropólogo disse a Andreza. Neste sentido, o crente-cidadão, de fato, 'alvoroça' os termos do debate ao se chocar com a economia moral das instâncias de esfera pública. Ainda assim, a maneira de se conduzir eticamente nessas instâncias não se faz na ausência da deliberação. É por isso que a estética do confronto não encontra o mesmo 
grau de intensidade na sua execução entre os jovens crentes com os quais conversei, na comparação com seu líder, o pastor Silas Malafaia

Até agora apresentei os momentos nos quais os jovens crentes devem falar a fim de se constituírem como crentes-cidadão. Ao apresentar este novo contexto, no qual as atitudes parecem contar mais do que as palavras, caminho para completar o conjunto das virtudes que conformam a constituição do crente-cidadão. Elas passam justamente pelo aprendizado do discernimento a respeito de se ele/ela deve ou não falar, e, se sim, em que contexto (posicionamento contextualizado ou nas instâncias de interação estruturadas como esfera pública), além de desenvolver a maneira correta de se conduzir moralmente nos momentos de demanda ética (ou desafio moral). Então, quando é mais eloquente não falar?

\section{Ética do evangelismo}

Outro aspecto importante a ser analisado na constituição do crente-cidadão pode ser depreendido de minha conversa com Michael, 22 anos, estudante de direito na Faculdade Estácio e que estava frequentando a ADVEC há seis meses no momento de nossa entrevista (apesar de já ser diácono e líder dos adolescentes em uma filial da igreja no bairro da Pavuna, zona norte do Rio de Janeiro). Perguntei a Michael se já havia ocorrido algum debate/embate a respeito do tema da homossexualidade em sua faculdade, ou se em algum momento ele teria mencionado para um colega de turma sobre o status de pecado que a igreja imputa à homossexualidade. Ele me contou sobre um amigo que, em seus dizeres, antes homossexual, havia se convertido por conta de seu testemunho.

- Como eram tuas conversas com ele? Uma vez que você entende que a homossexualidade é pecado, como você dizia isso pra ele, ele sendo seu amigo. Ele não se ofendia? Vocês chegaram a ter esse tipo de conversa?

- É que, na verdade, eu nunca disse. Eu nunca disse pra ele isso [que a homossexualidade é pecado]. Justamente porque o Espírito Santo de Deus convence o homem com amor, com um abraço. 
Paulo mesmo já fez isso. Ele ressuscitou um jovem, no livro de Atos 21:7, só abraçando. Ele não precisou falar nada. O jovem estava no terceiro andar assistindo Paulo pregar. Ele se distraiu, porque o discurso de Paulo era sonolento, e o jovem morreu... O jovem não queria ouvir, não se sentia atraído. Esse discurso de hoje está causando exatamente isso. [E] não só está causando sono, como [também] ódio. Então a gente tem que fazer exatamente como Paulo fez: parar de falar e usar palavras tão agressivas e passar a agir, dar um abraço. Então foi isso que fiz com [meu amigo homossexual que se converteu]. Eu não falava, eu dava um abraço. Eu acho que foi assim que eu expus o cristianismo pra ele.

Outro momento de minha conversa com Débora pode ajudar a esclarecer o ponto que quero enfatizar. Aqui ela fala sobre um colega de turma, também homossexual, sobre quem eu perguntei quais estratégias ela usava para evangelizá-lo, uma vez que, sendo da igreja de Silas Malafaia, adversário do movimento LGBT na esfera pública, as pessoas podiam resistir à sua presença:

Minha turma toda sabia que eu era da igreja do pastor Silas Malafaia. Porém, nós tínhamos um respeito mútuo muito grande, eu e esse meu colega [homossexual]. Então, eu evangelizava ele mais com atitudes do que com palavras. Então, minha intenção era que ele visse que independentemente de eu ser daqui [da igreja de Malafaia], [e de saber que eles dizem] "Ah, porque o pastor Silas é sem noção, é homofóbico”, eu queria que ele visse que na verdade não é isso. Que nós somos contra uma prática e não contra uma pessoa...

... Ele, como meu colega de classe, sempre foi muito gentil. Sempre que ele precisou de meus cadernos eu emprestei, e ele também me emprestou. Então eu falava mais com minhas atitudes, na verdade. Falava através do respeito, do carinho.

"Evangelize, se preciso use palavras”, foi o que Beatriz me disse ser a estratégia de proselitismo mais correta para utilizar entre as pessoas com as quais convivia. Ela continua: "A gente não precisar chegar para todo mundo e falar... não é assim que funciona. Você vive o evangelho com suas ações". Daniel vai mais além e critica o fato de a homossexualidade ser um assunto mais recorrente do que outros entre os crentes de sua igreja: 
... Da mesma forma que eu não falo para o meu chefe no emprego, "ah, você é ganancioso, ganância é pecado e você vai para o inferno", não vou dizer isso para um homossexual, seria evangelizar da forma errada. A própria Bíblia fala que a nossa vida é como um livro aberto. Mas isso é menos pelas opiniões que a gente emite em público, e mais por coisas que você vai construindo no dia-a-dia, na convivência. Às vezes você não tem que falar nada.

É interessante notar a diferença entre a atitude prescrita no código moral pentecostaharsh, mesmo aquela apresentada no que chamei de posicionamento contextualizado, e os momentos de evangelização que acabo de descrever. Enquanto naquelas interações não é permitido se calar e, principalmente no contexto das instâncias de esfera pública política, deve-se 'mostrar a cara', aqui, por outro lado, o silêncio é considerado mais eloquente. Comunicam atitudes como dar um abraço, respeito, carinho. Falar, apenas se preciso. E às vezes não se deve dizer nada. Parece, portanto, inevitável relacionar a ética do evangelismo como a vimos até aqui com a ética ordinária (Lambek 2010, 2015; Das 2010, 2012), ou seja, ao aspecto tácito da moral. 'Não falar nada', portanto, pode ser relacionado ao esforço ético presente nos pequenos atos, que acontecem sem chamar atenção indevida para si (Das 2012). A convivência de Débora com seu amigo homossexual, resumida por ela mesma na troca de gentilezas e no mútuo empréstimo dos cadernos, são ações eticamente carregadas nas quais a ética encontra-se implícita no ato, sendo objetivada somente a partir da provocação do pesquisador.

Porém, o evangelismo não prescinde do trabalho comunicativo da ética. Pelo contrário. Mostrei alhures (Mauricio Junior 2016; Campos \& Mauricio Junior 2013) como o 'dar uma palavra' ao seu irmão de fé, ou ao outro desconhecido é uma das principais definições do que significa 'ser usado por Deus'. A cadeia de circulação verbal que surge dessas práticas de si é uma das principais características da cultura pentecostal (ver também Mauricio Junior 2011; Campos \& Mauricio Junior 2012). Vejamos como funcionam, na prática, essas 
interações com Andreza contando como se sentiu usada por Deus na faculdade ao 'dar uma palavra' a uma colega:

... Ela estava passando por um momento muito difícil na vida dela. Tinha perdido os avós e estava em crise com os pais. E aí eu comecei a falar coisas para ela que depois eu não me lembrava que eu tinha falado... E eu comecei a falar, falar, falar, tentando de alguma forma confortar ela daquela situação. E depois quando eu acabei de falar, ela tava chorando muito com as coisas que eu falava. Ela só conseguiu me dizer "caramba, Andreza! Você falou coisas que eu só dizia para mim mesma, no meu íntimo, coisa que ninguém poderia saber"... Foi Jesus, né? que pediu pra eu falar aquilo para ela.

Os aspectos tácitos da moral no evangelismo (mantenha em mente o abraço de Michael e a troca de gentilezas de Débora) parecem estar intercalados, então, com os momentos de demandas éticas, seja do próprio evangelismo (como acabamos de ver com Andreza falando para sua amiga o que "Jesus pediu"), seja do pentecostaharsh. Pode-se, à primeira vista, corroborar com a análise de Zigon (2007) de que os momentos de desafio moral são como procedimentos táticos cujo objetivo é regressar ao estado de familiaridade moral irrefletida. No entanto, ao invés de buscarem voltar ao conforto do modo não -reflexivo das disposições morais cotidianas, os sujeitos pentecostais, como diz Coleman (2018), constituem-se na busca, e não fuga, dos desafios morais.

Para ser considerado cheio ou cheia do Espírito Santo, e assim, ser usado/usada por Deus, os jovens crentes precisam ter o tipo de experiência semelhante ao de Andreza, trazendo uma palavra de revelação à sua colega, para contar. Mover-se na direção do desconforto, neste caso, significa pôr-se sob o risco daquela palavra não ser acolhida. O desfecho, quando sua amiga disse ter pensado naquelas palavras apenas no seu íntimo e que por isso mais ninguém poderia sabê-las, poderia não acontecer e Andreza estaria submetida a uma situação frustrante e, no limite, ao ridículo. Mais risco ainda correm os jovens crentes nas interações pentecostaharsh, determinantes para que eles se automodelem - e sejam considerados por sua comunidade - como 
crentes-cidadãos. Desafiar o professor, ou a professora, como fizeram Beatriz e Andreza é colocar o preparo como crente-cidadão sob prova nos seus limites.

Não obstante, correr riscos nestes dois registros, o do evangelismo e o pentecostaharsh, parece exigir disposições virtuosas diferentes. "Falar, falar, falar" na interação na qual Andreza entregou as palavras mandadas por Jesus à sua amiga, não carrega a estética do confronto como nas interações pentecostaharsh. Enquanto nesta última é preciso fazer os adversários tremerem, no evangelismo vê-se a estética do confronto dando lugar a uma estética do acolhimento: o abraço de Michael, a oração de Beatriz, o consolo de Andreza, a gentileza de Débora, todos são exemplos característicos de uma ética do evangelismo, portanto. Por outro lado, na medida em que se tornou necessário engajar-se nas instâncias de esfera pública política, vencer o outro no debate argumentativo demandou observar uma estética do confronto, enquanto alternam-se códigos gramaticais como estratégia de legitimação do discurso. Arthur sistematiza a diferença entre o pentecostaharsh e a evangelização e posiciona a ética de ambas nos contextos dos debates e do evangelismo, respectivamente:

A evangelização é muito diferente do debate... tu não podes dar tua opinião forte quando tu estás evangelizando... [mas] claro que naqueles debates que eu vim para defender isso, você veio para defender aquilo, então vai pegar fogo, ok?

Como, então, o crente-cidadão decide a maneira de se conduzir eticamente quando dele se exige diferentes, e até contrastantes, modos éticos de conduta? Vimos como as instâncias éticas de segunda pessoa determinam as condições práticas de reflexividade (Keane 2014). A cena do discurso e da interação provoca o distanciamento dos sujeitos permitindo-os deliberar a respeito das instâncias de terceira pessoa das quais lançarão mão. $\mathrm{O}$ crente-cidadão em primeiro lugar, portanto, delibera a respeito de como se conduzir em um momento ético a partir de como o contexto da interação se estrutura (a definição da situação engendra a definição da conduta). É possível dizer, em suma, 
que a conduta dos jovens crentes com os quais convivi alternam-se entre o modo pentecostaharsh de se conduzir, seja no modo combativo das instâncias de esfera pública ou no que chamei de posicionamento contextualizado, e a ética do evangelismo com sua estética do acolhimento. Ainda assim, mesmo na interação pentecostaharsh, explica Arthur, é necessário treinar os afetos e as sensibilidades para que os jovens crentes continuem a serem reconhecidos como cristãos. Desse modo, o crente-cidadão é forjado engajando-se em interações que põem em risco sua (auto) definição como tal. Há um risco, no entanto, que de maneira alguma pode se concretizar: ter o seu 'exemplo de cristão' desmoralizado, como diz Arthur.

A atitude do cristão no debate é de extrema importância. Não adianta você chegar para um debate que alguém começa a gritar e você gritar também. Você tem que dar o exemplo como cristão! Claro, dando tua opinião, mas também dando exemplo de cristão... O que eu quero dizer é que meu exemplo de cristão está acima da minha opinião. Está acima de tudo, na verdade. Se eu sentir que eu vou me alterar, eu recuo um pouco. Se eu sentir que eu vou falar alguma coisa, se eu sentir que eu vou agredir a pessoa, eu tenho que recuar.

O crente-cidadão, portanto, conduz a si mesmo eticamente nos debates na relação com o código pentecostaharsh, mas o faz procurando se conhecer, buscando se controlar, pondo-se à prova, tentando o aperfeiçoamento em busca de uma modelagem de sensibilidades e de afetos que não o atrapalhem no caminho de tornarem-se crentes virtuosos. Arthur continua:

Na verdade, é difícil para o cristão. Não é fácil você chegar, mostrar ser um cristão e falar sua opinião, dizer tua opinião, entendeu?

Demonstrando ser sereno. Esta é a palavra: demonstrando ser sereno. Você tem que ter muito o dom do espírito santo da serenidade para conseguir debater um assunto que você é agredido.

Diante da declaração da necessidade do 'dom da serenidade' até mesmo para debater questões políticas e ao mesmo tempo sustentar o exemplo de cristão, uma questão se torna inevitável: Os jovens crentes 
com os quais convivi reprovam a estética do confronto incentivada por Malafaia, na forma dos embates que o próprio pastor travou na esfera pública? Arthur dá a resposta:

Quando a gente vê o pastor Silas discutindo, ali é debate. Aquilo é uma discussão. Ali o pastor Silas está sendo atacado e vai ter que atacar e defender o posicionamento dele... você vai chegar lá no debate e sabe que é inflamado, você vai ficar o que? Caladinho? [Já] quando ele for evangelizar, é muito diferente.

O que acontece, na verdade, é que os jovens crentes da ADVEC entendem que seu líder acessa instâncias superiores, as quais não estão ao alcance de suas vidas cotidianas. Nessas instâncias exige-se, inevitavelmente, segundo eles, uma conduta de confronto e combate, numa intensidade superior, até mesmo com relação aos momentos em que os próprios crentes-cidadãos lançam mão do modo pentecostaharsh de conduta. Seus líderes, portanto, estão combatendo o bom combate e a recompensa para o Reino advinda da conduta de Malafaia pode ser vista, como diz Beatriz:

Talvez esses tópicos estejam sendo discutidos da forma como são e a opinião evangélica está sendo ouvida da forma como é porque tem um cara que está falando desse jeito; do que se o cara falasse todo zen, talvez as pessoas não escutassem.

\section{Considerações finais}

Sendo assim, e em suma, espero ter mostrado a contento como entendo o crente-cidadão: como um sujeito moral que se auto constitui através das práticas de si, e que avalia, delibera, a respeito da melhor maneira de se conduzir, se no modo pentecostaharsh com sua estética do confronto, ou no contexto do posicionamento refletido, onde essa conduta é relativizada, ou ainda se o modo de conduta a ser acessado será baseado na ética da evangelização com sua estética do acolhimento. É uma noção de virtude informada pela necessidade de manter o exemplo de cristão que modela as sensibilidades e afetos necessários à maneira correta do crente cidadão se conduzir 
eticamente. Se dar o exemplo de cristão passa pelo dom do Espírito Santo de ser sereno, como disse Arthur, isso não significa que há um rompimento da lealdade com a liderança da igreja. Tratam-se de instâncias de interação estruturadas de diferentes maneiras, exigindo diferentes condutas.

\section{Notas:}

1 A igreja tem seu organograma formado por diversos departamentos cujos líderes são geralmente pastores. Esses, por sua vez, respondem ao pastor Silas Malafaia, presidente de ADVEC. O Universe está ligado ao departamento dos jovens.

2 Portal G1 - Mundo. 'Tabeliã americana cita Deus para negar licença de casamento a gays'. (http://g1.globo.com/mundo/noticia/2015/09/tabelia-americanacita-deus-para-negar-licenca-de-casamento-gays.html. Acesso em 21/01/2019).

3 Portal G1 - Mundo. 'Suprema Corte dos EUA aprova o casamento gay em todo o país’. (http://g1.globo.com/mundo/noticia/2015/06/suprema-corte-dos -eua-aprova-o-casamento-gay-nacionalmente.html. Acesso em 21/01/2019).

4 A igreja imprime folders convidando para os cultos, entrega aos seus membros e incentiva sua distribuição.

\section{Referências:}

CAMPOS, Roberta B. C. \& MAURICIO JUNIOR, Cleonardo. 2012. "Os Comensais da Palavra: Emoções e corpo na trajetória espiritual dos crentes da Assembleia de Deus”. Revista Brasileira de Sociologia da Emoção, 11(33):777799.

2013. "As formas elementares da liderança carismática: o verbo e a imagética na circulação do carisma pentecostal”. Mana, 19(2):249-276.

COLEMAN, Simon. 2000. The globalization of Charismatic Christianity: spreading the gospel of prosperity. Cambridge, Cambridge University Press.

. 2018. "Zonas Fronteiriças: Ética, Etnografia e o Cristianismo

'Repugnante”". Debates do NER, 19(33):271-312.

DAS, Veena. 2010. "Engaging the Life of the Other: Love and Everyday Life”. In LAMBEK, Michael (ed.): Ordinary Ethics: Anthropology, Language, and Action, pp. 376-99: New York: Fordham University Press. 
DAS, Veena. 2012. "Ordinary ethics". In FASSIN, Didier (ed.): A Companion to Moral Anthropology, pp. 133-149. Oxford: Blackwell-Wiley.

DURKHEIM, E. 2008. "A Educação Moral". Petrópolis: Vozes.

FAUBION, D. James. 2001. "Toward an Anthropology of Ethics: Foucault and the Pedagogies of Autopoiesis". Representations, 74(1):83-104.

FOUCAULT, Michel. 2010. Ditos EE Escritos V: Ética, sexualidade, politica. Rio de Janeiro: Forense Universitária.

HABERMAS, J. 2014. Mudança Estrutural da Esfera Pública. São Paulo: Editora Unesp.

KEANE, Webb. 2014. "Freedom, reflexivity, and the sheer everydayness of ethics". Journal of Ethnographic Theory, 4(1):443-457.

LAMBEK, M. 2010. Ordinary Ethics: Anthropology, Language, and Action. New York: Fordham University Press.

2015. The Ethical Condition: Essays on Action, Person, and Value. Chicago: Univ. Chicago Press.

MAURICIO JUNIOR, Cleonardo. 2011. Da cultura pentecostal ao líder carismático: Os crentes da Assembleia de Deus e a performance do pastor Silas Malafaia. Trabalho de Conclusão de Curso. Recife: Universidade Federal de Pernambuco. . 2016. Vasos nas mãos do Oleiro: a constituição do pastor pentecostal. Recife: Editora Universitária da UFPE. .2019. Como os evangélicos discutem política? A constituição do crente-cidadão entre os jovens universitários da igreja de Silas Malafaia. Tese de Doutorado. Recife: Universidade Federal de Pernambuco.

MEYER, Birgit. 2004. "Praise the Lord': Popular cinema and pentecostalite style in Ghana's new public sphere”. American Ethnologist, 31(1):92-110.

MONTERO, P. 2015. "Religiões e controvérsias públicas: experiências, práticas sociais e discursos". Coleção antropologia hoje: Terceiro Nome. Unicamp.

TAYLOR, Charles. 2011. "Why We Need a Radical Redefinition of Secularism". In: BUTLER, Judith et al (eds.): The power of the religion in the public sphere, pp. 34-59. Oxford: Columbia University Press.

ZIGON, J. 2007. "Moral breakdown and the ethical demand: A theoretical framework for an anthropology of moralities." Anthropological Theory, $7(2): 131-150$.

Abstract: This paper aims to analyze the ethical self-constitution in relation to the political among the young believers of Pastor Silas Malafaia's church, the Assembly of God Victory in Christ, in Rio de Janeiro. Taking into account the clashes that took place in the Brazilian public sphere on issues relating to sexual and reproductive rights which have placed on opposite sides leaders of Pentecostal churches and social movements, I say that 
ordinary faithful of these churches have received the moral responsibility to take a political stand in their everyday lives in the defense of themes dear to their value systems. 'Believer is also a citizen', says Malafaia to his followers and, therefore, 'has to take a stand'. I intend to show, then, how the young people of this church assume this mission, especially in their universities, defining their ethical conduct amidst the political tensions that have characterized Brazilian society today.

Keywords: Pentecostalism, Ethics, Politics, Believer-citizen.

Recebido em Abril de 2019.

Aprovado em Julho de 2019. 